\title{
Pengaruh Persepsi, Layanan Dan Keamanan Sistem Terhadap Minat Nasabah Menggunakan Aplikasi Mobile Banking
}

\author{
Nur Andayani' ${ }^{1}$ Basri Modding2 ${ }^{2}$, Amir Mahmud $^{3}$ \\ ${ }^{1,2,3}$ Magister Manajemen, Universitas Muslim Indonesia. \\ ${ }^{1}$ Koresponden Penulis, E-mail: anda.yani.ay@gmail.com
}

\begin{abstract}
ABSTRAK
Tujuan penelitian ini adalah 1) untuk mengetahui dan menganalisis pengaruh persepsi terhadap minat nasabah untuk melakukan transaksi ulang pada aplikasi mobile banking, 2) untuk mengetahui dan menganalisis pengaruh layanan terhadap minat nasabah untuk melakukan transaksi ulang pada aplikasi mobile banking, dan 3) untuk mengetahui dan menganalisis pengaruh keamanan sistem terhadap minat nasabah untuk melakukan transaksi ulang pada aplikasi mobile banking. Pendekatan penelitian adalah pendekatan kausal yang bersifat explanatory. Metode analisis yang digunakan dalam penelitian ini adalah metode analisis Regresi Berganda. Hasil penelitian menunjukkan bahwa 1) Persepsi berpengaruh positif dan signifikan terhadap minat nasabah untuk melakukan transaksi ulang pada aplikasi mobile banking pada BRI Kanca Tamalanrea, hal ini menunjukkan bahwa semakin baik persepsi yang dimiliki nasabah, maka semakin tinggi pula minat nasabah untuk melakukan transaksi ulang pada aplikasi mobile banking pada BRI Kanca Tamalanrea, 2) Layanan berpengaruh positif dan signifikan terhadap minat nasabah untuk melakukan transaksi ulang pada aplikasi mobile banking pada BRI Kanca Tamalanrea, hal ini menunjukkan bahwa semakin baik layanan yang diberikan karyawan, maka semakin tinggi pula minat nasabah untuk melakukan transaksi ulang pada aplikasi mobile banking pada BRI Kanca Tamalanrea, dan 3) Keamanan sistem berpengaruh positif dan signifikan terhadap minat nasabah untuk melakukan transaksi ulang pada aplikasi mobile banking pada BRI Kanca Tamalanrea, hal ini menunjukkan bahwa semakin baik keamanan sistem BRImo, maka semakin tinggi pula minat nasabah untuk melakukan transaksi ulang pada aplikasi mobile banking pada BRI Kanca Tamalanrea.
\end{abstract}

Kata Kunci: Persepsi; Layanan; Keamanan Sistem; Minat Nasabah

\begin{abstract}
The objectives of this study were 1) to determine and analyze the effect of perceptions on customer interest in retransactions on mobile banking applications, 2) to determine and analyze the effect of services on customer interest in re-transactions on mobile banking applications, and 3) to determine and analyze the effect of system security on customer interest in re-transactions on the mobile banking application. The research approach is a causal approach that is explanatory. The analytical method used in this research is the multiple regression analysis method. The results showed that 1) Perception has a positive and significant effect on customer interest in re-transactions on the mobile banking application at BRI Kanca Tamalanrea, this indicates that the better the perception of the customer, the higher the customer's interest in re-transacting on the application. mobile banking at BRI Kanca Tamalanrea, 2) Services have a positive and significant effect on customer interest in retransactions on mobile banking applications at BRI Kanca Tamalanrea, this shows that the better the service provided by employees, the higher the customer's interest in making transactions repeat on the mobile banking application at BRI Kanca Tamalanrea, and 3) System security has a positive and significant effect on customer interest in re-transactions on the mobile banking application at BRI Kanca Tamalanrea, this shows that the better the security of the BRImo system, the higher the pu He is interested in customers to re-do the mobile banking application at BRI Kanca Tamalanrea.
\end{abstract}

Keywords: Perception; Services; System Security; Customer Interest 


\section{PENDAHULUAN}

Perkembangan teknologi berkembang dengan sangat cepat dan hampir semua berbasis digital artinya tidak lagi memanfaatkan bantuan manusia akan tetapi menggunakan sistem yang canggih dan otomatis. Dampak dari perkembangan teknologi berbasis digital tersebut juga memengaruhi pertumbuhan teknologi di dunia perbankan. Saat ini, bank bersaing untuk menciptakan suatu layanan digital banking dimana layanan tersebut dapat memberikan kemudahan terhadap pemakainya. Mobile banking merupakan bentuk dari adanya perkembangan digital banking tersebut (Herlambang \& Arimbi, 2018).

Mobile banking adalah fasilitas layanan dalam pemberian kemudahaan akses maupun kecepatan dalam memperoleh informasi terkini dan transaksi finansial secara real time. Mobile banking dapat diakses oleh nasabah melalui ponsel yang memiliki teknologi GPRS. Produk layanan mobile banking adalah saluran distribusi bank untuk mengakses rekening yang dimiliki nasabah melalui teknologi GPRS dengan sarana telpon seluler. Perkembangan teknologi informasi yang sedemikian pesat sangat mendukung dalam kecepatan dan kemudahan layanan transaksi perbankan terhadap nasabah (Maulana, dkk., 2018).

BRI Mobile merupakan suatu aplikasi yang mengintegrasikan layanan e-banking di antaranya Mobile Banking. Pertumbuhan pengguna layanan mobile banking BRI juga terjadi di Kota Makassar. Dengan adanya layanan mobile banking BRI tersebut dapat memberikan kemudahan bagi para penggunanya. Meskipun layanan mobile banking $B R I$ memberikan kemudahan-kemudahn kepada para penggunanya, akan tetapi terdapat beberapa pengguna yang mengeluhkan atau kurang nyaman pada saat menggunakan layanan tersebut. Keluhan yang disampaikan oleh pengguna tersebut yaitu mengenai notifikasi transaksi yang tidak terkirim atau terlambat. Meski notifikasi tidak terkirim atau terlambat hal tersebut tetap mengurangi biaya pulsa pengguna (Herlambang \& Arimbi, 2018). Diantara faktor yang mempengaruhi minat nasabah untuk melakukan transaksi ulang pada aplikasi mobile banking antara lain adalah persepsi, layanan dan keamanan system.

(Kaplan, 2010) menyebutkan bahwa persepsi nasabah perbankan dalam meningkatkan minat nasabah untuk melakukan transaksi ulang pada aplikasi mobile banking diukur dengan persepsi manfaat, persepsi kemudahan, persepsi kepercayaan, persepsi kenyamanan dan persepsi risiko. Kotler (2012) menyatakan bahwa layanan sangat diperhatikan oleh costumer (nasabah), jika suatu bank memberikan layanan yang baik maka akan memberi kepuasan terhadap nasabah. Nasabah harus memperoleh kepuasan dan salah satunya dari tersedianya sarana dan prasarana yang baik yang disiapkan pihak bank, melayani secara cepat dan tepat. Budi (2015) keamanan informasi adalah bagaimana kita dapat mencegah penipuan (cheating) atau paling tidak, mendeteksi adanya penipuan di sebuah sistem yang berbasis informasi, dimana informasinya sendiri tidak memiliki arti fisik.

Pada dasarnya nasabah akan berminat menggunakan mobile banking ketika kegunaan dan kemudahan dalam menggunakan layanan tersebut sesuai dengan nasabah, Begitu juga dengan faktor risiko dan kepercayaan yang di berikan oleh pihak bank. Namun sebaliknya, ketika nasabah menganggap faktor tersebut tidak sesuai maka 
nasabah kurang berminat menggunakan mobile banking. Selain itu tidak sedikit nasabah yang belum mau menggunakan layanan mobile banking karena merasa layanan tersebut tidak sesuai dengan harapan

Berdasarkan uraian tersebut, maka kerangka konseptual penelitian ini adalah:

Gambar 1. Kerangka Konseptual Penelitian

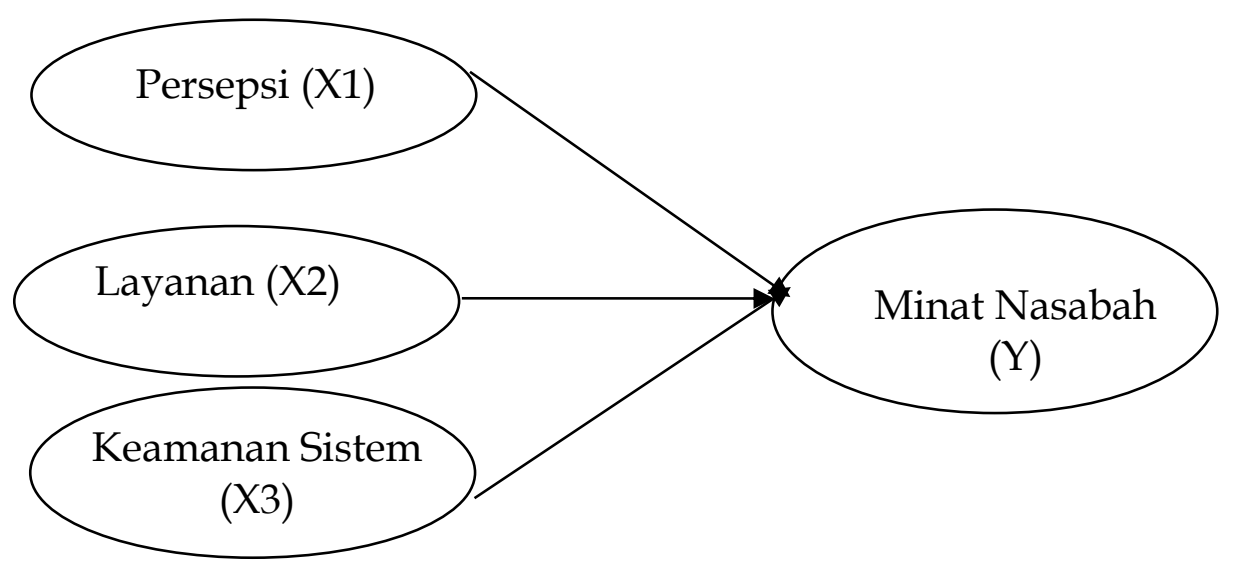

\section{Hipotesis}

Berdasarkan latar belakang masalah dan kajian teori maka hipotesis dalam penelitian ini yaitu:

1. Persepsi berpengaruh positif dan signifikan terhadap minat nasabah untuk melakukan transaksi ulang pada aplikasi mobile banking.

2. Layanan berpengaruh positif dan signifikan terhadap minat nasabah untuk melakukan transaksi ulang pada aplikasi mobile banking.

3. Keamanan sistem berpengaruh positif dan signifikan terhadap minat nasabah untuk melakukan transaksi ulang pada aplikasi mobile banking

\section{METODE PENELITIAN}

Pendekatan dalam penelitian ini menggunakan pendekatan kuantitatif, dimana Pendekatan penelitian yang digunakan adalah kuantitatif. Populasi dalam penelitian ini adalah nasabah BRI Kanca Tamalanrea yang menggunakan aplikasi mobile banking sampai pada Desember 2019 berjumlah 81.768 orang nasabah. Sampel adalah bagian dari jumlah dan karakteristik yang dimiliki oleh populasi tersebut. Untuk mengetahui jumlah sampel digunakan, maka pada penelitian ini didasarkan atas pendapat Slovin (Umar, 2013), sehingga jumlah sampel adalah 100 orang nasabah. Metode analisis data yang digunakan adalah regresi berganda.

Penelitian dilakukan di Kota Makassar, Provinsi Sulawesi Selatan. Tepatnya pada BRI Kanca Tamalanrea.

\section{Uji Hipotesis}

a. Uji Koefisien Determinasi $\left(\mathrm{R}^{2}\right)$

Nilai $\mathrm{R}^{2}$ digunakan untuk mengukur seberapa jauh kemampuan model dalam menerangkan variasi variabel dependen. Pada penelitian ini yang digunakan 
adalah adjusted $\mathrm{R}^{2}$ dapat naik atau turun apabila satu variabel independen ditambahkan kedalam model. Nilai yang mendekati satu berarti variabelvariabel independen memberikan hampir semua informasi yang dibutuhkan untuk memprediksi variabel dependen (Ghozali, 2014).

b. Uji Regresi Simultan (Uji Statistik F)

Uji statistic F dilakukan dengan tujuan untuk menguji apakah keseluruhan variabel independen mempunyai pengaruh secara bersama-sama terhadap variabel dependen. Ghozali (2014). Pengujian simultan ini dilakukan dengan berpedoman pada hipotesis uji berikut :

$\mathrm{H}_{0} ; \beta \mathrm{I}=0$ melawan $\mathrm{H}_{\mathrm{a}} ; \beta \neq 0$ Kriteria Pengujian :

Jika $\mathrm{F}_{\text {hitung }}<\mathrm{F}_{\text {tabel }}$ atau $\mathrm{P}>0,05$ maka $\mathrm{H}_{0}$ diterima

Jika Fhitung $\geq \mathrm{F}_{\text {tabel }}$ atau $\mathrm{P}<0,05$ maka $\mathrm{H}_{0}$ ditolak

Jika Ho diterima, berarti secara simultan, semua koefisien tidak berbeda nyata nilainya dengan 0 pada tingkat kepercayaan $95 \%$. Dengan demikian, hasil analisis regresi tidak dapat dipakai untuk melakukan pendugaan secara statistic, seperti membuat ramalan mengukur korelasi dan determinasi. Sebaliknya jika $\mathrm{H}_{0}$ ditolak, berarti secara simultan (bersama-sama) semua koefisien regresi berbeda nyata nilainya dengan 0 pada tingkat kepercayaan 95\%. Dengan demikian, hasil analisis regresi dapat dipakai untuk melakukan pendugaan secara statistic

c. Uji t (Parsial)

Untuk mengetahui ada tidaknya pengaruh variable bebas terhadap variable terikat, maka dilakukan pengujian hipotesis yang diajukan pada penelitian ini. Metode pengujian terhadap hipotesis yang dilakukan pengujian secara parsial menggunakan uji t. uji $t$ menunjukkan seberapa jauh pengaruhnya variable independent.

Untuk menguji apakah masing-masing variable bebas berpengaruh secara signifikan terhadap variable terikat secara persial dengan menentukan derajat kepercayaan $95 \%(a=0,05)$ dan juga penerimaan atau penolakan hipotesis. Maka cara yang dilakukan adalah :

1) Ho : $b_{1}=0$, artinya variabel $X$ tidak mempunyai pengaruh yang signifikan secara persial terhadap variabel $Y$

2) Ha: $b_{1} \neq 0$, artinya variabel $X$ mempunyai pengaruh yang signifikan secara persial terhadap variabel $Y$

3) Taraf signifikan menggunakan 0.05

Dengan membandingkan $t$ hitung dengan table Apabila $t$ hitung $>t$ kritis Ho diterima, Apabila t hitung $<\mathrm{t}$ kritis Ho diterima.

\section{HASIL PENELITIAN DAN PEMBAHASAN}

\section{Hasil}

Pengaruh simultan variabel $X_{i}$ (persepsi, layanan dan keamanan sistem) terhadap variabel Y (minat nasabah) untuk melakukan transaksi ulang pada aplikasi mobile banking pada BRI Kanca Tamalanrea dapat diketahui juga dari koefisien determinasi 
serentak $\left(\mathrm{R}^{2}\right)$. Ini dapat diketahui dari hasil analisis Determinasi Simultan pada tabel 1 sebagai berikut:

Tabel 1. Hasil Uji Determinasi

\begin{tabular}{lrrrrr}
\hline \multicolumn{5}{c}{ Model Summary } \\
Model & $\mathrm{R}$ & R Square & $\begin{array}{c}\text { Adjusted R } \\
\text { Square }\end{array}$ & $\begin{array}{c}\text { Std. Error of the } \\
\text { Estimate }\end{array}$ \\
\hline 1 &, 795 a &, 632 &, 621 &, 35907 \\
\hline a. Predictors: (Constant), Keamanan Sistem, Layanan, Persepsi & &
\end{tabular}

Nilai R Square (R2 ) sebesar 0,632. Ini berarti, pengaruh variabel $X_{i}$ (persepsi, layanan dan keamanan sistem) secara simultan terhadap variabel $Y$ (minat nasabah) untuk melakukan transaksi ulang pada aplikasi mobile banking pada BRI Kanca Tamalanrea adalah $63,2 \%$ dan pengaruh variabel lainnya sebesar 36,8\%.

Tabel 2. Hasil Uji Simultan

\begin{tabular}{|c|c|c|c|c|c|c|}
\hline \multicolumn{7}{|c|}{ ANOVA $^{a}$} \\
\hline \multicolumn{2}{|c|}{ Model } & $\begin{array}{l}\text { Sum of } \\
\text { Squares }\end{array}$ & $\mathrm{df}$ & $\begin{array}{c}\text { Mean } \\
\text { Square }\end{array}$ & F & Sig. \\
\hline 1 & Regression & 21,263 & 3 & 7,088 & 54,972 &, $000^{b}$ \\
\hline & Residual & 12,377 & 96 & 129 & & \\
\hline & Total & 33,640 & 99 & & & \\
\hline
\end{tabular}

a. Dependent Variable: Minat Nasabah

b. Predictors: (Constant), Keamanan Sistem, Layanan, Persepsi

Nilai $F_{\text {hitung }}$ sebesar 53,695 dengan level signifikansi 0,000 atau nilai $p_{\text {value }}<0,05$. Berdasarkan kriteria pengujian hipotesis, maka $\mathrm{H}_{0}$ ditolak dan $\mathrm{H}_{\mathrm{a}}$ diterima. Ini berarti secara simultan semua variabel independen memiliki perbedaan nyata dengan 0 .

Hipotesis diuji dengan menggunakan uji signifikansi parameter individual (Uji Parsial). Uji ini digunakan untuk menguji tingkat signifikansi pengaruh variabel independen terhadap variabel dependen secara parsial atau secara sendiri-sendiri. Pengambilan keputusan dilakukan berdasarkan perbandingan nilai $t$ hitung masing-masing koefisien $t$ regresi dengan $t$ tabel sesuai dengan tingkat signifikansi yang digunakan yaitu 0,05. Hasil uji signifikansi parameter individual (Uji t) disajikan pada tabel berikut ini:

Tabel 3. Persamaan Regresi

\begin{tabular}{|c|c|c|c|c|c|c|}
\hline \multicolumn{7}{|c|}{ Coefficients $^{a}$} \\
\hline & $\begin{array}{r}\text { Unst } \\
\mathrm{Co} \\
\end{array}$ & $\begin{array}{l}\text { ndardized } \\
\text { fficients }\end{array}$ & $\begin{array}{c}\text { Standardiz } \\
\text { ed } \\
\text { Coefficients }\end{array}$ & & & \\
\hline Model & $\mathrm{B}$ & Std. Error & Beta & $\mathrm{t}$ & Sig. & \\
\hline 1 (Constant) &,- 047 & ,377 & &,- 125 & & 901 \\
\hline Persepsi & ,352 & 119 & 304 & 2,952 & & ,004 \\
\hline Layanan & 365 & 083 & ,316 & 4,389 & & ,000 \\
\hline Keamanan Sistem & 312 & 106 & ,315 & 2,953 & &, 004 \\
\hline
\end{tabular}

a. Dependent Variable: Minat Nasabah 
Persamaan regresi: $Y=-0,047+0,352 X_{1}+0,365 X_{2}+0,312 X_{3}$

\section{Interpretasi data :}

Nilai -0,047 artinya apabila variabel persepsi $\left(X_{1}\right)$, layanan $\left(X_{2}\right)$ dan keamanan sistem $\left(\mathrm{X}_{3}\right)$ tidak mengalami perubahan (konstan), maka minat nasabah (Y) untuk melakukan transaksi ulang pada aplikasi mobile banking pada BRI Kanca Tamalanrea tidak akan berubah.

Nilai 0,352 artinya setiap peningkatan variabel persepsi $\left(X_{1}\right)$, maka diharapkan dapat meningkatkan minat nasabah $(\mathrm{Y})$ untuk melakukan transaksi ulang pada aplikasi mobile banking pada BRI Kanca Tamalanrea sebesar 35,2\%.

Nilai 0,365 artinya setiap peningkatan variabel layanan $\left(X_{2}\right)$, maka diharapkan dapat meningkatkan minat nasabah (Y) untuk melakukan transaksi ulang pada aplikasi mobile banking pada BRI Kanca Tamalanrea sebesar 36,5\%.

Nilai 0,312 artinya setiap peningkatan variabel keamanan sistem $\left(X_{3}\right)$, maka diharapkan dapat meningkatkan minat nasabah $(Y)$ untuk melakukan transaksi ulang pada aplikasi mobile banking pada BRI Kanca Tamalanrea sebesar 31,2\%.

Analisis uji hipotesis dalam penelitian ini untuk membuktikan Hipotesis dalam penelitian ini yaitu: Pertama, hasil uji hipotesis membuktikan nilai signifikasi persepsi dengan nilai Sig sebesar 0,004 lebih kecil dari $a=0,05$ sehingga hipotesis yang menyatakan Persepsi berpengaruh positif dan signifikan terhadap minat nasabah untuk melakukan transaksi ulang pada aplikasi mobile banking pada BRI Kanca Tamalanrea terbukti. Kedua, hasil uji hipotesis membuktikan nilai signifikasi layanan dengan nilai Sig sebesar 0,000 lebih kecil dari $a=0,05$ sehingga hipotesis yang menyatakan Layanan berpengaruh positif dan signifikan terhadap minat nasabah untuk melakukan transaksi ulang pada aplikasi mobile banking pada BRI Kanca Tamalanrea terbukti. Ketiga, hasil uji hipotesis membuktikan nilai signifikasi keamanan sistem dengan nilai Sig sebesar 0,004 lebih kecil dari $a=0,05$ sehingga hipotesis yang menyatakan Keamanan Sistem berpengaruh positif dan signifikan terhadap minat nasabah untuk melakukan transaksi ulang pada aplikasi mobile banking pada BRI Kanca Tamalanrea terbukti.

\section{Pembahasan}

1. Pengaruh Persepsi Terhadap Minat Nasabah

Hasil uji hipotesis membuktikan nilai signifikasi persepsi dengan nilai Sig sebesar 0,004 lebih kecil dari a = 0,05 sehingga hipotesis yang menyatakan Persepsi berpengaruh positif dan signifikan terhadap minat nasabah untuk melakukan transaksi ulang pada aplikasi mobile banking pada BRI Kanca Tamalanrea terbukti. Hasil ini sejalan dengan teori yang dikemukakan oleh Kotler (2012) bahwa persepsi nasabah merupakan proses nasabah dalam memilih, mengelola dan menginterpretasikan informasi yang diterima dan selanjutnya akan dilakukan respon atas informasi tersebut, artinya bahwa pada saat melakukan persepsi, stimulus yang sama kemungkinan akan menghasilkan persepsi yang berbeda pada setiap individu karena kemampuan 
berpikir, pengalaman, dan perasaan yang berbeda pada individu ikut berperan dalam pembentukan persepsi individu. Hasil penelitian selaras dengan penelitian yang dilakukan oleh Adi, dkk (2019) yang menunjukkan bahwa persepsi kegunaan berpengaruh positif terhadap niat dalam menggunakan aplikasi mobile banking nasabah perbankan konvensional di Kota Palu.

\section{Pengaruh Layanan Terhadap Minat Nasabah}

Hasil uji hipotesis membuktikan nilai signifikasi layanan dengan nilai Sig sebesar 0,000 lebih kecil dari $a=0,05$ sehingga hipotesis yang menyatakan Layanan berpengaruh positif dan signifikan terhadap minat nasabah untuk melakukan transaksi ulang pada aplikasi mobile banking pada BRI Kanca Tamalanrea terbukti. Hasil ini sejalan dengan teori yang dikemukakan oleh (Tjiptono, 2014) bahwa layanan merupakan setiap tindakan atau kegiatan yang dapat ditawarkan oleh satu pihak kepada pihak lain pada dasarnya tidak berwujud dan tidak mengakibatkan kepemilikan. Layanan perbankan untuk transaksi keuangan banyak diberikan oleh bank dengan tujuan utama memberikan kemudahan nasabah dalam bertransaksi. Hasil penelitian ini selaras dengan penelitian yang dilakukan oleh (Ayu, 2018) yang menunjukkan bahwa variabel pelayanan berpengaruh signifikan terhadap minat nasabah yang dibuktikan dengan nilai t hitung sebesar 6,082 > 1,987 dan nilai signifikan 0,00< 0,05 maka dapat disimpulkan bahwa H0 ditolak dan H2 diterima yang artinya kualitas pelayanan berpengaruh signifikan terhadap minat nasabah.

\section{Pengaruh Keamanan Sistem Terhadap Minat Nasabah}

Hasil uji hipotesis membuktikan nilai signifikasi keamanan sistem dengan nilai Sig sebesar 0,004 lebih kecil dari a =0,05 sehingga hipotesis yang menyatakan Keamanan Sistem berpengaruh positif dan signifikan terhadap minat nasabah untuk melakukan transaksi ulang pada aplikasi mobile banking pada BRI Kanca Tamalanrea terbukti. Hasil ini sesuai dengan Undang-undang tentang Perlindungan Nasabah Pasal 1 angka 28 UU 10/1998 tentang rahasia bank yang menyangkut keterangan mengenai nasabah penyimpan dan simpanannya dan Pasal 40 ayat (1) dan (2) UU 10/1998 tentang kewajiban bank merahasikan keterangan mengenai nasabah penyimpan dan simpanannya. Tingginya kebutuhan akan bertransaksi yang mudah, aman dan cepat menuntut BRI Kanca Tamalanrea meningkatkan pelayanan khususnya di bidang keamanan sistem informasi agar dapat menjawab tantangan saat ini. Saat ini nasabah lebih memilih bertransaksi melalui mobile banking, bukan melalui antri di bank. Dengan semakin banyaknya transaksi berbasis online maka memicu meningkatnya penggunaan mobile banking, dimana sudah menjadi kebutuhan wajib bagi kaum urban dan milineal saat ini. Perkembangan teknologi sangat berpengaruh terhadap penerapan mobile banking, guna mewujudkan transaksi perbankan yang mudah, cepat, dan aman. Adanya realita ini pihak BRI Kanca Tamalanrea wajib memperhatikan keamanan sistem, dimana merupakan komponen penting agar tetap menjadi pilihan nasabah. 


\section{KESIMPULAN}

Berdasarkan hasil penelitian dan pembahasan, maka dapat ditarik kesimpulan sebagai berikut: Persepsi berpengaruh positif dan signifikan terhadap minat nasabah untuk melakukan transaksi ulang pada aplikasi mobile banking pada BRI Kanca Tamalanrea. Layanan berpengaruh positif dan signifikan terhadap minat nasabah untuk melakukan transaksi ulang pada aplikasi mobile banking pada BRI Kanca Tamalanrea. Keamanan sistem berpengaruh positif dan signifikan terhadap minat nasabah untuk melakukan transaksi ulang pada aplikasi mobile banking pada BRI Kanca Tamalanrea.

\section{DAFTAR PUSTAKA}

Adi, P. Fadli, Saleh, F.M. Zahra F. dan Afdhalia. N. (2019). Faktor-faktor Yang Mempengaruhi Niat Dalam Menggunakan Mobile Banking. Jurnal Akun Nabelo. Vol 2 No 1. Universitas Tadulako.

Ayu. W. (2018). Pengaruh Fasilitas dan Pelayanan Terhadap Nasabah Menabung di Bank Syariah. Jurnal. UIN Raden Intan Lampung.

Budi. R. (2015). Keamanan Sistem Informasi Bebasis Internet. PT. Insan Indonesia. Jakarta.

Ghozali, I. (2014). Aplikasi Analisis Multivariate dengan Program IBM SPSS19. Penerbit: Badan Penerbit UnDip. Semarang.

Herlambang, A. D. dan Arimbi. D. (2018). Minat Nasabah Dalam Menggunakan Layanan Mobile Banking. Jurnal Ilmiah Teknologi Informasia Asia. Vol 12 No 01. Universitas Brawijaya.

Indonesia, (1998). Undang-undang Pasal 1 angka 28 UU 10/1998, tentang Perlindungan Nasabah.

Kotler, P. (2012). MarketingManagement: Analysis, Planning, Implamentation, and Control. 11 th edition (New Jersey: Prantice-Hall International Inc.

Maulana, R, Iskandar dan Masrura. M. (2018). Pengaruh Penggunaan Mobile Banking Terhadap Minat Nasabah Dalam Bertransaksi Menggunakan Technology Accept Model. Jurnal Pendidikan Teknologi Informasi. Vol 2 No 2. UIN Ar-Raniry Aceh.

Tjiptono, F. (2014). Pemasaran Jasa. Malang : Bayumedia. Malang.

Umar, H, (2013). Metode Penelitian untuk Skripsi dan Tesis Bisnis. Edisi Kedua. PT Raja Grafindo Persada, Jakarta. 